\title{
Migrations during the Soviet Period and in the Early Years of USSR's Dissolution: A Focus on Central Asia
}

Migrations pendant la période soviétique et après la fin de l'URSS : regard sur l'Asie centrale

Migraciones durante el período soviético y los primeros años después de la caída de la URSS: acento en Asia central

Delia Rahmonova-Schwarz

\section{OpenEdition}

Journals

Electronic version

URL: https://journals.openedition.org/remi/5196

DOI: 10.4000/remi.5196

ISSN: $1777-5418$

\section{Publisher}

Université de Poitiers

\section{Printed version}

Date of publication: 1 December 2010

Number of pages: 9-30

ISBN: 978-2-911627-56-9

ISSN: 0765-0752

\section{Electronic reference}

Delia Rahmonova-Schwarz, "Migrations during the Soviet Period and in the Early Years of USSR's

Dissolution: A Focus on Central Asia", Revue européenne des migrations internationales [Online], vol. 26 $n^{\circ} 3$ | 2010, Online since 01 December 2013, connection on 15 February 2023. URL: http://

journals.openedition.org/remi/5196 ; DOI: https://doi.org/10.4000/remi.5196 


\title{
Migrations during the Soviet Period and in the Early Years of USSR's Dissolution: A Focus on Central Asia
}

\section{Delia RAHMONOVA-SCHWARZ ${ }^{1}$}

\begin{abstract}
Central Asia is a region with strong migratory dynamics. Migration patterns from Central Asia have their roots in the policies of the Soviet state on mobility and labor. As this volume comprises a number of interesting country-specific cases, it is important to bear in mind that the region as a whole has for the past century witnessed various flows of in - and out - migrations including state-forced resettlements during the Soviet people. The present article has the objective to describe on the one hand state-forced migration movements during the Soviet period, and on the other hand, the opportunities for and restrictions on mobility that influenced the migration patterns during this time. These migration-related historical developments should be drawn to the attention of scholars studying the current migration flows within the region as well as between the region as the place of origin and other countries of migrant destination.
\end{abstract}

Central Asia is also home to people who represent various ethnic groups and languages. For example, there are ethnic Uzbeks, Russians, Koreans and Tatars in Kyrgyzstan or Tajikistan or a Tajik-speaking population in some parts of Uzbekistan, ethnic Russians, Uigurs and many other minorities in Kazakhstan, Uzbeks and Russians in Turkmenistan. Scholars dealing with migration from Central Asia to Russia, a major point of destination, to Kazakhstan or beyond the post-Soviet territory are often confronted with this ethnic heterogeneity. This article also sheds light on movements of people in the context of state nationality policies during the Soviet period. Finally, this contribution shows that labor-induced migration as seen on the post-Soviet territory had begun prior to the dissolution of the USSR.

1 Policy Support Officer, OSCE Conflict Prevention Centre, Wallnerstrasse 6, 1010 Vienna, Austria; schwarzdelia@web.de 


\section{THE EARLY YEARS OF MOBILITY CONTROL IN PRE-SOVIET RUSSIA}

Any person travelling nowadays to Russia or to some countries of the former Soviet Union has been confronted with a mandatory registration of residence, known in Russian as propiska or registraciia. Researchers of post-Soviet migrations have without a doubt heard from both internal migrants within Central Asian countries or in the Russian Federation about their difficulties obtaining legal documents of which propiska is an important part. Resident registration has an interesting history. Some scholars hold Tsar Peter the Great responsible for the initial concept of registering population in order to engage more recruitees for his reformed army, collect taxes, and rule with more law and order than his predecessors (Garcelon, 2001: 90). Others argue that as early as the end of the $16^{\text {th }}$ century the tsars kept a systematic registration of peasants who were bound to work for the feudal lords (Matthews, 1993: 1).

Under the regulations of the Russian tsars, the individual choice for mobility, particularly among the peasants, was limited. Movements of people took place for commercial or professional reasons whereas personal travels were highly restricted. However, subjects of higher ranks such as nobles and higher military personnel were issued permanent passports and enjoyed freedom of movement. The lower the rank, the more constrained the subjects were in their mobility. In cities, especially in St. Petersburg and Moscow, the subjects who were registered temporarily received address tickets that they were demanded to retain until their departure (Matthews, 1993: 10-12).

By the mid-19 $9^{\text {th }}$ century, strict control over population mobility became a hindrance as the demand for blue collar manpower increased together with industrialization of the urban areas. Issuance of passports became expensive for the impoverished, and consequently residents became increasingly reluctant to abide by the rules. In 1894, when the Statute on Residence Certificates was adopted under Alexander III, it was no longer demanded that urban residents obtain a permanent permit. When Central Asia was annexed to the Russian Empire in the 1860s, the statute loosened control over travels of subjects even more.

\section{CONTROL OF MOVEMENT THROUGH LABOR IN THE PERIOD AFTER THE 1917 REVOLUTION}

After the toppling of the tsarist regime and the establishment of the Bolshevik power, management of migration, settlement, and employment gained importance in the newly founded socialist state's policies towards forming a large multiethnic state - one in which every member would work to contribute to the favor of the socialist society. Following the October revolution, Bolsheviks who had been vigorously criticizing and intending to abolish the tsars' oppressive policies towards the exploited class soon established full control over the entire population with the same firmness. What is remarkable is that with a similar attitude as the tsars had had towards peasants whose movement they had restricted, the Bolsheviks demanded that all former members of bourgeoisie and upper 
classes obtain residence registrations. In doing so, the Bolsheviks compelled the former "exploiters" to participate in the military service and socially beneficial labor such as construction and maintenance. Holders of registration cards, who were adult men aged 18 to 45 , were obliged to have their employment information entered into their documents by their employers and trade unions. This procedure was followed by the policy of "labor books" implemented in October 1918 (Matthews, 1993: 16-19). The regulation initially applied to all people who had previously belonged to upper classes. Labor books were to substitute identity documents and passports. They contained personal data and all information on jobs assumed by the holder, who had to update it on a monthly basis at the local administrative or police offices. Most importantly, labor books had a special entry on the holder's place of residence (Matthews, 1993: 16-19). Propiska, the term for "residence registration" that emerged initially as an entry in these labor books, was a tit-for-tat instrument of control in the onset of the Bolshevik power. This practice would survive decades of state migration policies during and after the Soviet period and would be widely used in the ex-Soviet countries.

Shortly after the introduction of "labor books" for members of the formerly upper class, in December 1918 RSFSR employment legislation stipulated that every workable individual acquire a "worker's book" (rabochaia knizhka), a document which would include information on the place of employment, hours of service, salaries, vacations, sick leaves, maternal leaves, rewards, promotions, and penalties. As of February 22, 1922, any employment and/or leave of a worker involved permission from the local labor officials. Until recently in the years after the fall of the Soviet Union, a similar document called "trudovaia knizhka" (work book) served as evidence for inter alia, determining years of work to calculate pension rates. Between 1924 and 1925, after a one-year period of liberalization of regulations concerning population movements, a legislation was adopted which stated that any person assuming residence for at least three days must register with the landlords, administrator of the residence, or a hotel. Individuals receiving visitors had to register them with a law enforcement office within 48 hours upon their arrival. ${ }^{2}$ Details about the person were to be entered into the "house book" (domovaia kniga) (Matthews, 1993: 20; Buckley, 1995: 902). This book was to be kept at every abode with a detailed record of its residents; it too maintained its significance until the $21^{\text {st }}$ century in each of the four countries involved in labor migration.

\section{MANAGING MIGRATION AND INSTITUTIONALIZING RESTRICTION ON MOVEMENT OF PEOPLE UNDER STALIN}

When considering the institutional constraints imposed on the movements of people during the Soviet period, it is important to keep in mind the Soviet state's construction of nationalities in the 1920s and 1930s. It is during this period that allocation of geographical territories of the Soviet republics took place. One of the most important historical milestones is the year 1922, which marked the establishment of the Soviet

2 According to the Federal Law on Migration Registration of Foreign Citizens and Stateless Persons of the Russian Federation adopted in January 2007, the host party is required to notify the Federal Migration Service about the arrival of a foreign visitor. 
power in Turkestan - the region which later became known as Central Asia - as well as the foundation of the Union of the Soviet Socialist Republics (USSR). Two years later, in 1924, when the delimitation of administrative borders in Central Asia resulted in the creation of the Turkmen SSR and the Uzbek SSR, the latter first included the Tajik ASSR into its territory. Tajik ASSR then became Tajik SSR in 1929. Kazakhstan was known as Kazakh Autonomous Soviet Socialist Republic of the RSFSR. To RSFSR belonged also Kara-Kyrgyz Autonomous Oblast' (Province). In 1936, these administrative unites were renamed Kazakh SSR and Kyrgyz SSR, respectively.

In the mid 1920s, the Soviets launched their first population census. For this purpose, they engaged ethnographers who had been working for the Commission for the Study of the Tribal Composition of the Population of Russia (Hirsch, 2005). Prior to this period, the ethnographers' primary task had been to gain ethnographic data for the Russian Empire during the First World War. Following the October revolution, when they became consultants to the Bolsheviks, they were committed to all-Union censuses and participated in the activities that involved defining the internal frontiers of the Soviet Union. The Russian ethnographers carried out field research in remote areas to conduct in-depth study of different peoples of the USSR. However, as Hirsch argues, they did far more than merely accumulate data in the remotest places of the USSR; they contributed to a change in population composition by applying an approach that Hirsch terms as "state-sponsored evolutionism." According to her, the state, which was marked by a strong Leninist school of thought, envisioned the evolution of the population of the USSR. The Soviets, adhering to the Marxist ideology of development, held that it was feasible to expedite the evolution process by forming nationalities through clustering clans and tribes which in turn were deemed to be residuals of the feudal period (Edgar, 2004; Hirsch, 2005). ${ }^{3}$ Nationalities would be formed into socialist-era nations, which some day in the era of communism would all be united. In Lubin's words, "a 'flourishing of nations' was to lead to their eventual 'coming together,' or 'rapprochement,' which was ultimately to lead to their 'merging' or assimilation." (Lubin, 1984: 6). ${ }^{4}$ Thus, in compliance with the government's official list of nationalities, citizens had to choose or declare themselves as belonging to an official nationality during individual encounters with census-takers (Hirsch, 2005: 9).

A further relevant aspect for the study of post-Soviet migration is the principle of "double assimilation" applied by the Soviet regime. The characteristic of this kind of assimilation is the co-occurrence of top-down and bottom-up processes, which meant that not only did the Soviet government implement measures from above such as delineating national borders and publishing an official list of nationalities, but also that local elites were involved in the decision making and had to fight for resources, land, and power. Archival materials bear witness to the fact that even smaller population groups such as

3 Hirsch's elaborate work leaves an impression that the creation of ethnicities/nationalities in Central Asia occurred mainly beginning with the formation of the USSR, particularly under Stalin. Earlier scholarship on Central Asia points out that already in the $19^{\text {th }}$ century the tsars had the tendency to perceive of "people" by the language spoken by people (Volk). This German romanticism was then passed onto Marxists who advanced their own vision of constructing nations following the revolution in 1917 (Roy, 2000: 54).

4 More on "merging" (sliianie) and "coming together" (sblizhenie) of nations, see also Smith (1996: 8-9). 
peasants protested and complained to higher authorities about inappropriate distribution of their territories to the national territorial units they desired not to be part of (Hirsch, 2005; Edgar, 2004: 53, 60-61). ${ }^{5}$

Prior to the formation of the Soviet Union and the enhancement of the state nationality policies, the sense of identification with which Central Asian people associated themselves was based on their language, clan, tribe, geographic place, religion, and religious and/or noble ancestry (Roy, 2000: 48-60; Edgar, 2004: 18; Hirsch, 2005: 110-114). The border delimitation and the first all-Union census of 1926 gradually altered people's sense of self-identification, as the Soviet republics in Central Asia would include national majorities and minorities. Roy points out that the delimitation of these borders did not have any geographic, economic, or ethnic rationality. This resulted, as he rightly points out, in the emergence of such complex constellations of peoples as the large Uzbek population for which the Province of Osh in the south of Kyrgyzstan is known, or the ethnic Uzbeks living in Tashauz and Charjau (now Türkmenabad) in Turkmenistan as well as Shymkent and Jambul in Kazakhstan. In Tajikistan, the Uzbek speaking population is spread primarily in the north in the Sughd Province and the region of Hissor as well as some villages in the Province of Khatlon in the south. Similarly, in Uzbekistan, there is a large Tajik-speaking population in Buxoro, Samarqand, Surxondaryo, and even in the Ferghana Valley and the north of Tashkent. There are ethnic Kyrgyz in the north and south of Tajikistan (Roy, 2000: 116-118). ${ }^{6}$

In the midst of the border demarcation process and creation of nations, the party-state was especially responsible for controlling rural out-migration and managing mobility of the population. The establishment of the Soviet power resulted in emigration of thousands of people who opposed the communists. In the Central Asian republics, the former upper class people were marginalized and driven from urban to rural areas. The formation of socialist collective farms led thousands of better-off peasants to flee from the Soviet regime into exile. Particularly in the 1930s, the so-called kulaks, or rich peasants/entrepreneurs, were taken under state scrutiny. Repression and execution of the kulaks forced a great number of people to seek refuge in Afghanistan, Iran, China, Turkey, Saudi Arabia, and in Western European countries (Kocaoğlu, 2000). In nomadic regions of Turkmenistan, Uzbekistan, Kyrgyzstan, and Kazakhstan, collectivization was used as a tool to bring about a sedentary lifestyle. As Edgar argues, nomads were perceived by the Soviet administration as people difficult to control, who were opposed to the Soviet power

5 Edgar points out interesting examples from the 1920s in which Soviet ethnographers were unable to determine the nationality of certain nomadic tribes based on their languages. There were cases in which the Soviet authorities found it extremely difficult to distribute certain territories during the border delimitation process.

6 I refrain from referring to the Tajik-speaking population as Tajiks and the Uzbek-speaking population as Uzbeks. The Soviet citizenship passport had a special nationality entry. Following the demise of the USSR, when the citizenship passports in each Central Asian country were introduced, the citizens in Central Asian countries were once again confused. Either the citizenship passports did not have such an entry (Uzbekistan) or representatives of ethnic/linguistic minorities were categorized according to their place of birth, as in the case of Tajiks who were registered as Uzbeks since they had been born in Buxoro in the 1940s and moved to Tajikistan during the Soviet era. They do not necessarily speak Uzbek. 
and prone to cross the Soviet border to flee. According to Soviet understanding, only those who possessed a great deal of wealth were able to afford to lead a nomadic life, as any change of place of residence with family and household would require considerable means (Edgar, 2004: 195).

The first Five-year Plan which was launched in 1928 marked a head start towards the "modernization of culturally backward people", sedentarization, and enhancement of development through industrialization and collectivization of agriculture (Edgar, 2004: 88; Collins, 2006: 85). ${ }^{7}$ At the same time, the Soviets implemented a policy of distribution of labor that they coupled with strict migration control. It is in this context that the Central Asia region started receiving labor migrants from Russia through orgnabors, an organized system of labor force recruitment for the mining industry, railway and motorway construction, technical personnel for construction of factories and plants, etc. (Shigabdinov and Nikitenko, 2000: 104).

In 1932, Stalin issued a decree according to which internal passports were to be issued - allegedly - not only in order to gain more precise statistical information from urban areas, but also "in order to secure the deportation from these places of persons who are not connected with industry or with work in offices and schools, and who are not engaged in socially useful labor (with the exception of infirm persons and pensioners), and also in order to cleanse these places of kulak, criminal and other anti-social elements finding refuge there..." (Matthews, 1993: 28).

The decree applied to any individual older than 16 years residing in border zones, urban areas, or towns (or within $100 \mathrm{~km}$ around them) ${ }^{8}$ Four months after this legislation was issued, it was complemented by a further decree determining a list of 25 towns and $100 \mathrm{~km}$ radiuses to which the decree would apply. All other individuals living beyond the officially designated "regime zones" were deprived of passports and were required to be registered with the rural district authorities. This meant that minority populations who had been allocated to reside in designated territories (army members and, particularly, peasants, i.e. collective farmers who constituted a majority among the population) were also Soviet citizens, but they had difficulty traveling and seeking residence and employment as they wished in the areas which were under strict control through internal passports. Without a passport it was impossible to travel to distant locations since boarding trains and buses required showing a valid internal passport. Only on a seasonal basis and with the permission of their supervisors were members of kolkhozes allowed to work in the spheres of industry and construction (Lewis and Rowland, 1979: 22). In addition, under the oppressive regime of Stalin, defiance of passport and registration rules was punished. Penalties varied from fines to a prison sentence of up to two years; forgery of documents was severely prosecuted (Lewis and Rowland, 1979: 22; Matthews, 1993: 28; Garcelon, 2001: 91).

7 Specifically on internal migration control and collectivization, see Garcelon (2001).

8 Hirsch mentions that the internal passport system of the USSR distinguished between three territorial categories: (1) "regime zones," which encompassed territories of geopolitical or economic importance that later would include surrounding regions within $100 \mathrm{~km}$ designated as such, as well as frontier regions that were located $100 \mathrm{~km}$ within the Soviet territories bordering the European and Far Eastern states, (2) "non-regime zones," the term applied to rural regions and provinces, and (3) "extra-administrative zones" that included the Gulag (2005: 275). 
In light of the Soviet efforts to develop industry and cotton monoculture in Central Asia, arid oases in the south were to be cultivated. Due to a great deficit of manpower in these parts of the region, groups of population were relocated involuntarily from the Ferghana Valley to these areas. During the period from 1929 until the mid-1950s, in accordance with Stalin's oppressive attitude toward kulaks and other 'undesired' minority population in Central Russia and Siberia, "special settlements" (spetsposelenie) were established in the region where these forced settlers had to reside (Shigabdinov and Nikitenko, 2000: 103). A typical example is the deportation of 171,781 Koreans to Kazak and Uzbek SSR in the late 1930s, which occurred due to increased Soviet suspicion of ethnic Koreans residing in the frontier territories of the Far East. The Soviets feared that ethnic Koreans might establish close ties to Korean nationals and Japanese intelligence agents with Korean nationality (Shigabdinov and Nikitenko, 2000: 104).

The period during World War II and the years immediately after witnessed, despite the strict control on movement, different migration flows including rural-to-urban movements due to the increase of industrialization and expansion of urban areas. Migration of Slavic population to Central Asia increased during and after World War II, partly related to the evacuation of population from Russian territories under the German occupation, but also as a result of the transfer of plants, construction of military infrastructure, provision of clothing and food supplies, and redistribution of resources during the war (Shigabdinov and Nikitenko, 2000: 104). Among the Central Asian republics, Kyrgyz SSR and Kazakh SSR had the largest inflow of Russian-speaking migrants in the decades after World War II (Islamov, 2000: 181-182).

The onset of World War II and the invasion of the Nazi troops marked the deportation of Germans from the Volga Region to Central Asia, their overall number in 1941-1942 amounting to 1,209,430. Forced relocation of minorities in the USSR was not confined only to Germans, however. The number of "special settlements" grew as Chechens, Ingushes, Crimean Tatars, Kurds and Greek political migrants were resettled forcefully into various regions of Central Asia (Polyan, 2001; Berdinskikh, 2005). For instance, a relatively large group of around 60,000 Meskhetian Turks was resettled from Georgia to the Ferghana Valley in Central Asia in 1944 (Rubin and Lubin, 2000: 177). Almost 40,000 Greeks were relocated from the Black Sea region, mainly to Kazakhstan and Uzbekistan during the same period (Bugai and Kotsonis, 1999: 55, 117).

Notwithstanding the adoption of strict policies such as the introduction of mandatory registration at the place of residence and the internal passport system, there seems to have been some difference between policy and practice. Lewis and Rowland as Buckley state that in reality, those wishing to change their place of residence succeeded in doing so by using informal channels. Lewis and Rowland argue that despite the common understanding in the West that Stalinist policies severely restricted mobility, one should contextualize the migration regulations of that time. The decline of the economy, extreme poverty, starvation and collectivization of the 1920s and 1930s led the population to move to urban areas. Between 1926 and 1939, as Soviet statistics states, 18.7 million people migrated from rural areas into urban areas (Lewis and Rowland, 1979: 25). In spite of the limitations imposed on the cities that were officially "closed" to migrants from outside through the notorious propiska (residence permit) regulation, many potential migrants 
sought different alternatives such as informal practices to attain their goals and eventually succeeded in settling. An elaborate study conducted by Buckley shows that in reality, the restrictive measures of the Soviets to control the vast growth of the cities were quite unsuccessful (Buckley, 1995).

\section{MIGRATION PATTERNS IN THE 1960'S AND 1980'S}

\section{The Presence of the Slavic Population in Central Asia}

During this period the Central Asian republics experienced a sharp increase of demographic growth. The population of the RSFSR slightly declined, with the exception of some industrial regions (Gibson, 1991: 152). The statistical data on the changes of residence of individuals within the USSR show that the population of the Central Asian republics remained relatively immobile, whereas in RSFSR people showed more mobility and moved between different regions (Lubin, 1984: 41; Gibson, 1991). For the period of 1959-1979, the Central Asian republics report the following data on the increase of the population among the titular nationalities: Uzbekistan (6.7\%), Kyrgyzstan (7.5\%), and Tajikistan (5.8\%) (Islamov, 2000: 182).

With Khrushchev's arrival to power in 1956 and his policy of de-Stalinization, control over workers' mobility was loosened. Through the orgnabors (the aforementioned organized labor recruiting service), the government continued to administer the distribution of labor force, relocating 28 million people in the period between 1930 and 1970. This organized recruitment was not mandatory, however. From 1951 until 1970, the number of resettled workers decreased, totaling merely 573,100 in the period of 1966-1970 (Lewis and Rowland, 1979: 19; Lubin, 1984: 42-43).

By the mid-1970s collective farmers that reached the age of 15 were permitted to obtain internal passports with which they were able to travel longer distances. The sources provided by Islamov (2000) suggest that in the time period of 1959-1979, Kyrgyzstan, Tajikistan, and Turkmenistan saw an increase of $13.1 \%, 8.5 \%$, and $10.9 \%$ of ethnic Russians, respectively. By 1970, around 30 million Russians were residing in areas primarily inhabited by non-Russians that were located beyond the administrative borders of the RSFSR. This number constituted 23 percent of the overall Russian population. Between 1979 and 1989, however, more Russians were reported to have left Central Asia than to have arrived (Shigabdinov and Nikitenko, 2000: 104). Gibson notes that the number of migrants from RSFSR to Central Asia dropped by 50\% during the period of 1971-1980 (Gibson, 1991: 153). The post-Stalinist period was marked by the redistribution of power and education and employment opportunities among Russian-speaking professionals and representatives of the so-called titular nationality. As argued by Korobkov (2008: 71), with regional governing bodies in Central Asia promoting more employment and education opportunities for the titular nationality, Russian speakers were pushed to take lower-level jobs which in turn led them to leave the region. 


\section{Emigration of the Jewish Population}

The period between late $1960 \mathrm{~s}$ and $1980 \mathrm{~s}$ is characterized by a large-scale emigration of Jews from the entire Soviet Union (including Central Asia). Prior to this period, the USSR had never before witnessed a mass permanent outflow of its citizens. In September 1968, the Embassy of the Netherlands in Moscow launched the issuance of exit permits that would allow Jews immigration to Israel (Buwalda, 1997: 9-11). ${ }^{9}$ What is more, it occurred at the time when very few citizens were given permission to travel to foreign countries. By 1971, the outflow of the Jewish minority increased sharply. Within this year, at least 13,000 people were allowed to leave. A year after, almost three times as many Jews left the USSR for Israel. Buwalda (1997) distinguishes between two waves within this exodus of the Soviet Jews. The first wave is in 1970s when 220,000 people emigrated. During this period the majority of Jewish emigrants left for Israel. Between 1975 and 1987, two thirds of the emigrants preferred to settle in countries other than Israel (Dietz, 2000: 639). The second wave started in 1987 and continued through 1991, with the number of Jewish emigrants amounting to 300,000 (Buwalda, 1997: 9-11).

The shift from strict controls on travel abroad to sweeping permission of such a great number of the population to emigrate in the midst of the Cold War seems remarkable. In this context, too, we should address the opportunities and constraints that shaped this pattern of migration. Zaslavsky and Brym (1983: 2-3, 64-76) discuss in their joint work the extrinsic and intrinsic modes in the scholarship on Jewish out-migration from the Soviet Union. The first of the two approaches links the outflow of the Jewish population to external factors occurring in the late 1960s and 1970s. The revival of the Jewish national consciousness and the strong desire of the Soviet Jews to emigrate to Israel is explained as an outcome of the Six Day War in 1967, in which Israel claimed victory, as well as the foundation of the state of Israel thereafter. In this context, it should not go unmentioned that the Kremlin was against Israel during the Six Day War, and this position had a major impact on the Jewish community all over the USSR. A further factor in this approach is the pressure which the West exerted on the USSR due to its desire that Jews leave the country. ${ }^{10}$

The second approach is related to social changes occurring within the confines of the USSR, and shifts the external factors to the background. The extent to which the Jewish out-migration took place is explained in terms of the Soviet preventive policy of a sudden deficit in labor force, particularly in the technical and scientific spheres. A further reason is argued to have been individual decision making: some had merely no desire to

9 The period of the late 1960s and early 1970s is considered by scholars such as Buwalda to be the second exodus of Jews. Buwalda points out that the first exodus of Jews took place in the period of 1881-1914 in which roughly 2 million Jews left the Russian Empire.

10 Zaslavsky and Brym provide some details about how Soviet-American trade agreements correlated with the attitude of the Kremlin's number of permissions for Jews to exit. Thus, in 1972-1973 when the wheat agreement was signed, between 32,000 and 35,000 emigrants were recorded. The Jackson-Vanik amendment, which warned that trade would be blocked if Jews were not permitted to leave, caused a decrease of exits. Further wheat accord resulted in an increase of emigration permissions, which then declined with the start of the Soviet military actions in Afghanistan in 1980 and the wheat embargo. 
abandon the society in which they had been brought up, whereas others were induced to emigrate by having heard the stories of their friends and relatives.

There are indeed a number of other push and pull factors which cannot be analyzed here. ${ }^{11}$ One of the most important and detrimental implications of the Jewish emigration from the Soviet Union has been brain-drain. It is worthwhile to point out this aspect, since the onset of brain-drain out of the Soviet Union became discernible in the republics of the Central Asian region that had been home to thousands of Jews throughout many centuries. ${ }^{12}$ It is difficult to determine precisely how many Jewish scientists, professionals, and skilled workers in total emigrated from Central Asia between 1970 and 1991. On the one hand, statistical data accumulation in the Soviet Union is a controversial topic in the sense that, in the context of anti-Semitic attitudes towards Jews, some individuals had chosen to identify themselves as belonging to different nationalities. On the other hand, in their quantitative data and discussions on the issue, some Western scholars (notably in the US) seem to have an anti-Soviet bias. What becomes clear is that Soviet authorities must have sensed the danger of brain-drain as a serious consequence of emigration when they imposed a so-called 'education tax' in August 1972..$^{13}$ According to this regulation, every emigrant had to compensate the Soviet state for the free education that they had obtained before their departure. The cost of emigration was in some cases as high as five to ten years of wages of a professional employee (Zaslavsy and Brym, 1983: 64). Other sources state that the fee was 4,500 rubles for a graduate in the humanities and 19,400 rubles for a doctor of sciences. Towards the end of that same year, the education fee had to be abolished, as the Western countries and President Johnson of the US threatened the USSR with sanctions (Buwalda, 1997: 91).

Although Western scholars working on this subject claim that, due to the antiSemitism that was present during the Soviet Union, the overall percentage of Jews who obtained higher education was only $1 \%$ in the entire USSR, having lived in the vicinity of a Jewish district, I cannot confirm the accuracy of such a low percentage in Central Asia. What became easily noticeable throughout the last two decades of the Soviet era was the absence of Jewish academicians, university professors, teachers, medical doctors, and scientists. In addition to brain-drain, the emigration of Jews meant the ultimate loss of a culture which was unique in its own, that had been developed and passed on through generations. Inherent to it were architecture, artisanship, music, and art of which almost no traces are left, and to which scholars focusing on emigration generally tend to pay too little attention.

11 There is an entire body of research in and outside of the former Soviet Union that deals specifically with Jewish emigration from the Soviet Union, including topics such as the Stalinist attitude towards nationality policy (Hirsch, 2005; Zaslavsky and Brym, 1983), the rise of antiSemitism in Russia (Zaslavsky and Brym, 1983), persecution and discrimination of Jews in the USSR (Buwalda, 1997), Soviet Jewish immigrants in Israel (Berthomière, 2003), and the Jewish minority population that chose not to emigrate (Ryvkina, 1996).

12 According to the sources provided by Zaslavsky and Brym, the total number Jews in 1970 in Uzbekistan was 102,855; Tajikistan, 14,615; and in the Kyrgyz Republic, 7,680.

13 This is not to deny that there was certainly more than mere fear of brain-drain when the authorities in the USSR established education fees. The historical passage of movement control in the USSR that covers the period prior to the Jewish emigration shows that the authorities most probably intended to prevent emigration. 


\section{"Friendship of Nations" and Construction of a Multiethnic Soviet Society: Education Migration, Internationalization of the Division of Labor and Solidarity among Nations}

In 1966, an earthquake of 7.5 on the Richter scale devastated the city of Tashkent, the capital of Uzbek SSR. Immediately, it became a major incentive for the Soviet authorities to reconstruct a new modern city that would embody the Soviet rhetoric of the "friendship of nations". The Soviet urban planners took necessary advantage of the damage caused by this natural disaster. They wiped out the majority of the residential buildings in the old town of Tashkent. The reconstruction efforts involved construction of multi-storied concrete residential buildings, schools, and hospitals, as well as creation of new industries and measures to develop infrastructure. This resulted in the inflow of thousands of migrants, particularly from the Slavic regions of the USSR. Around 30,000 people are estimated to have settled yearly during the early 1970s, all of them set to design Tashkent as a multicultural city epitomizing the "friendship of nations" (Lubin, 1984: 42; Roman, 2002; Sahadeo, 2007).

What is interesting and has been neglected in the research is that immediately after the earthquake, some higher education institutions in Tashkent evacuated their students and transferred them to the RSFSR. Despite scarce research which has been done particularly on the issue of outmigration after the earthquake, empirical data for the present study has indicated that some students among this generation settled in their new locations in Russia permanently. During my field research I encountered a case in which one of the former students had meanwhile become an important person in a patronage network of Central Asian migrants.

Along with the Russification policies and the efforts to raise the level of education in the less-developed peripheries of the USSR such as the Caucasus and Central Asia, the late 1960s through early 1980s was a period during which the educated youth, often the children of the party cadres and education elites, went to Russia to study at higher education institutions. Many of them came back to their region of origin as expected and pursued promising careers; some, however, chose to settle in Russia. From 20042007, Sahadeo conducted a survey with this precise category of migrants who had lived in the cities of Leningrad and Moscow during the Soviet era, who serve as evidence for the existence of an entire generation of education migrants in Russia and who recount different attitudes they received in their Slavic host societies (Sahadeo, 2007).

Research conducted by Lubin in late 1970s, which focuses mainly on Soviet Uzbekistan, brings two further aspects into the foreground, whose are of great significance for the present study: firstly, according to Lubin, the Central Asian (specifically Uzbek SSR) workable population migrated to the RSFSR for vocational, professional, and educational purposes. Secondly, she mentions that the Soviet Army served as a channel through which male migrants from Central Asia were allocated to different Russian cities. Lubin states that no data had been published on those migrants who had chosen not to return to Uzbekistan and that the individuals she had interviewed showed strong willingness to return to Uzbekistan (Lubin, 1984: 43). However, we do know in the meantime that some migrants did opt to stay permanently in Russia. Indeed, census data indicates that in 1959, 
42,000 Uzbeks were residing outside the territory of the Central Asian region. In 1979 the number of such migrants doubled, but considering that the number of the Uzbeks in the entire USSR was 12.5 million, 91,000 residing outside Uzbek SSR, seems miniscule (Lubin, 1984: 43).

According to sources provided by Sahadeo, in 1970 140,000 Kyrgyz, Tajiks, Uzbeks, and Turkmens were registered as residents in Russia. This number increased to 248,000 in 1989 (Sahadeo, 2007: 563). The present study will show that precisely these types of pioneer migrants - originating from all Central Asian republics, arriving in the 1960s and 1970s and staying in Russia, meanwhile maintaining ties to their regions of origin - played a crucial role in forming labor migrant networks in the 1990s. As we shall see in the course of this study, these actors became significant propellers of the inflow of cheap labor force. Those whose ties to their homelands had been rather weak benefited from their resources in Russia, and established migrant organizations and recruitment offices or have acted as informal job brokers and supervisors. ${ }^{14}$

\section{Russia's First Central Asian Labor Migrants?}

Military service and education were not the sole purposes for Central Asians to migrate to Russia for longer terms. Contrary to the common impression that the current mass labor migration from the Central Asian republics of the former Soviet Union to the Russian Federation commenced in the late 1990s, sufficient data has been found that implies the phenomenon of labor force movement from Central Asia to Russia is not characteristic of the post-Soviet period. While I argue that the dynamics of labor migration has represented a new challenge to the newly independent states, there was a period not too long before 1991 when the Soviet state encouraged the able-bodied population of Central Asia to settle in the regions of Russia that had labor deficit for the sake of resource allocation and production.

During the 1970s together with urbanization and industrialization in the RSFSR, the party-state staged efforts to cultivate the virgin land to increase food supplies, which of course required labor force. Soviet demographers criticized and complained about the absolute reluctance of Central Asia's workable population to migrate to different regions of the USSR to work. They stated that it was firstly due to a lack of education of Central Asians and secondly because the regions in Russia with severe labor deficit were not appealing to Central Asians in cultural, social, and material terms. The third argument was that the potential migrants were fairly satisfied with the environment in which they were living, regardless of the economic challenges of the period (Wimbush and Ponomareff, 1979: 11).

14 Here, we should be cautious about developing the two abovementioned aspects into categories such as education/vocation and military migrants as one might be tempted to. Among Lubin's interviewees there were namely those who stayed to study in Russian after the military service, which can make clear distinctions difficult. Similar cases emerged during my own fieldwork in Russia from 2005-2008. 
It goes without saying that the vast mobility of labor from Central Asian countries to Russia since the end of 1990s described in this volume has refuted these statements. What should be made clear is that there is significant historical data about movements of people from Central Asia to RSFSR during the Soviet period. In the second half of the 1970s, the Soviets expanded their agricultural development projects in the grey and brown earth zones of Moscow and Novgorod (known as the non-black earth zone, Rus. nechernozem) that extend to the north and the east of Russia, the territory covering Murmansk and the Urals (Wimbush and Ponomareff, 1979). It was planned that by 1980, the non-black earth zone would produce one-sixth of the overall agricultural production of the whole USSR (Wimbush and Ponomareff, 1979: 18-19). Development of agriculture in the non-black earth zone, the lower Volga, and Siberia, as well the establishment of Baikal-Amur Railroad, entailed engaging manpower from the regions with more labor force (Lubin, 1984: 43, 256; Gibson, 1991: 149). In 1978 the first group consisting of 1,200 Uzbeks was sent, and a year later as many as 3,900 were sent to the non-black earth zone to contribute to the development of agriculture (Lubin, 1986: 43). While both Lubin and Gibson provide us with marginal information on this topic and treat it within a broad macro-level study, I was able to explore some details of this phenomenon from newspaper articles published in the early 1980s.

In an article concerning Uzbek workers who opted to stay in the non-black earth zone, the Tashkent newspaper Yosh Leninchi (Uzb. 'Young Leninist') published an interview with Uzbek workers of both Slavic and Uzbek origin who expressed their strong desire to stay in Novgorod, Russia, and work there "not temporarily, but permanently." 15 Uzbek workers are quoted as promising that they will not go anywhere "until we turn the nonblack earth lands into a productive area...". According to another report, Uzbek workers, as their names suggest, meanwhile married local Russian women, founded families, and were provided with apartments (Sahadeo, 2007: 562). They did not return to Uzbekistan, even though their training had finished long ago. Uzbek migrants and their families are described as living a normal life. More weddings were planned to be celebrated the year after the report and concert ensembles from Uzbekistan were reported to be on tour in the Russian region.

Newspapers from other Central Asian republics attest that these projects were not limited to the Uzbek SSR. The newspaper Kommunist Tadzhikistana reported on May 15, 1983 that an entire train had left Dushanbe, the capital of Tajik SSR, for Khabarovsk, carrying 70 families or more than 300 people, whose average age was 30 . This train was the second to follow the first one that had left two months previously with 100 families. The report cited the train supervisor as saying that all the migrants [ $\mathrm{sic}]$ were bound to the Far East to live and were skilled people. Experienced drivers, crane truck operators, technicians, construction specialists, and engineers with previous professional experience specifically in land cultivation projects in Kazakhstan were being sponsored by the Soviet

15 Notes from the Nonchernozem Zone. Article by Gh. Shermuhamedov, in Yosh Leninchi, $25^{\text {th }}$ of March, 1983. United States. (1983). USSR, post report. Washington, D.C.: U.S. Dept. of State. The articles which I have been able to consult in the archives were in the form of short reviews translated from the original language. The reviews reflected relevant press articles published in the Kyrgyz, Tajik and Uzbek SSRs during the 1980s. The name Nonchernozem was translated as such from Uzbek into English. 
government to work and live in the Far East. G.D. Dzhavov, deputy chairman of the Tajik SSR State Committee on Labor, stated that within that five-year period, Tajikistan intended to send 6,000 workers to the Far East. The deputy chairman contended with pride that Tajikistan would do its own share in the projects of the Far East. ${ }^{16}$

Lubin's findings about Central Asian workers' definite plans to return to their native regions resulted from her fieldwork which she had carried out in the late 1970s, i.e. shortly after these projects started. We can see from sources dating to several years later though, that a considerable number of these migrants did opt to stay. The scarcity of data on Kyrgyzstan does not mean that its population was not affected by organized interregional labor. As far as this country is concerned, only one source mentions that in the 1980s approximately 30,000-40,000 workers were engaged from Kyrgyzstan in other Soviet republics, among their 6,000-9,000 are reported as students from the Kyrgyz SSR. They were involved mostly in construction sites, in groups known as stroiotriads (Abazov, 2000: 231).

A further aspect which is particularly relevant in the context of migration and labor is again the rhetoric of the "friendship of nations" with which these migrant workers were mobilized. Among the workers from Central Asia there were both ethnic Slavic and Central Asian nations, as the names of the persons suggest. What is really remarkable is the way the interviewees stress that they had been working in a multiethnic environment. As one engineer states, his group consisted of "representatives of 14 nationalities working selflessly." 17 Attention should be drawn also to the "group approach" with which the Soviet leadership mobilized the outmigration of Central Asians. By sending entire groups or collectives, as they were called, the leadership intended to facilitate the adjustment of these workers in the region of arrival. In 1976, according to the decree of the Central Committee of the CPSU, Uzbek SSR was commissioned to assign construction trusts or groups to carry out land reclamation work in Novgorodskaia and Ivanovskaia oblasts within the framework of the aforementioned non-black earth cultivation project. ${ }^{18}$ In Novgorod, for instance, the trust was called Uznovgorodstroi and had 2,500 members in 1979. In addition to irrigating and draining land and constructing houses, schools, and hospitals, the trusts had to found state farms and give them as gifts to their oblasts before

16 "Bon Voyage! Tadzhikistan to the Aid of the Country", L. Serebrennikov L., in Kommunist Tadzhikistana, 15th of May, 1983. United States. (1983). USSR, post report. Washington, DC: US Dept. of State.

17 Notes from the Nonchernozem Zone. Article by Gh. Shermuhamedov in Yosh Leninchi, $25^{\text {th }}$ of March, 1983. United States. (1983). USSR, post report. Washington, DC: US Dept. of State.

18 Construction "trusts" (in Russian trust) consist of a group of industrial or commercial enterprises with centralized direction (cf. Oxford Russian-English Dictionary, 1973). The official name of the resolution was "Ob obiazatel'stvax kollektivov vodoxoziaistvennykh i stroititel'nykh organizatsii Uzbekskoi SSR po okazaniiu pomoshchi Ivanovskoi i Novgorodskoi oblastiam v vypolnenii postanovleniia CK KPSS i Soveta Ministrov SSSR po dal'neishemu razvitiiu sel'skogo xoziaistva nechernozemnoi zony RSFSR." [On the obligations of groups belonging to organizations in charge of water management and construction of the Uzbek SSR in its assistance in Ivanovsk and Novgorod Provinces in the framework of the decree of the Central Committee of the CPSU on further development of agriculture in non-black zone of the RSFSR] (Wimbush and Ponomareff, 1979: 14, also Ref. 35). 
their departure, as it was planned to make the region a major supplier of vegetable, meat, and dairy products. The two state farms in Novgorod were proudly named Tashkent and Druzhba (Rus. "friendship").

These examples describe that, firstly, the Soviet state made efforts to design a multicultural society and promoted cooperation between different republics. Secondly, by creating facilities for Central Asian youths to study outside of their region of origin, especially in the RSFSR and by sending young recruitees from the region to serve in the Soviet Army, the 'merger of nations' was sponsored further. Thirdly, through shifting different skilled human resources between the regions within the USSR, the Soviet state supported its own development through migration strategy that should be addressed as characteristic in its own way. Ultimately, studies conducted by Sahadeo, Roman, and Hirsch contend that the Soviet ideology of internationalization privileged Russians over non-Russians and thus engendered more ethnic discrimination towards the non-Slavic population in Russia.

\section{MIGRATIONS IN THE LATE 1980'S AND THE DEMISE OF THE USSR: WITHER "FRIENDSHIP OF NATIONS" AND "BROTHERHOOD OF PEOPLES"?}

In June 1989, when the USSR was facing a major economic crisis, interethnic clashes took place in the Ferghana Valley of Uzbek SSR between Uzbeks and the Meskhetian Turks who had been resettled during the Stalinist period. A fight that started at a small market kindled major violence against Meskhetian Turks in the cities of Ferghna, Kokand, Marilan, and Namangan. According to official reports, 171 people died as a result of the violent clashes and the vast majority of them were Meskhetian Turks. (Rubin and Lubin, 2000: 45-46; Megoran, 2002: 243). As a reaction to these clashes, the Soviet government relocated almost all 15,000 Meskhetians out of Uzbekistan (Rubin and Lubin, 2000: 45-45, 177).

In the following month, in July 1989, ethnic clashes broke out between Tajiks and Kyrgyz in the Isfara Raion in the north of Tajikistan that borders with Kyrgyzstan. Around 5,000 ethnic Kyrgyz refugees from Tajikistan settled in the south of Kyrgyzstan (Smith, 1996: 397). A series of other inter-ethnic violence acts followed suit. ${ }^{19}$ In midFebruary in Dushanbe, the capital of Tajikistan, there was a failed attempt of a coup d'état. Opponents of Mahkamov, the First Secretary of the Supreme Soviet of the Tajik SSR, plotted it by spreading rumors that thousands of Armenians fleeing from the clashes in Nagorno-Karabakh would be provided with housing and employment. The riot which was triggered by these rumors cost the lives of 22 people. As a result, representatives of ethnic

19 To these events one can add the inter-ethnic clashes between Kyrgyz and ethnic Uzbeks in Southern Kyrgyzstan in June 1990. More on this in the context of economic crisis in Kyrgyzstan, see Abazov (1999). Not much research has been done however, with regard to the impact of 1990 inter-ethnic clashes on the out-migration ethnic Uzbeks. While the author is cognizant of the most recent June 2010 violent inter-ethnic clashes in Southern Kyrgyzstan, this topic cannot be treated in this article. Furthermore, it will have to be seen to what extent the population from the South, both ethnic Uzbeks and Kyrgyz will choose to migrate to other countries. 
minorities such as Russians, Germans, Armenians, and Bukharan Jews, a total number of about 100,000, left Tajikistan (Smith, 1996: 380). The same false rumors about Armenian refugees settling in Frunze (now Bishkek), Kyrgyzstan resulted in mass protests. Although the skirmishes in Bishkek did not have any consequences related to migration, the ideology of "friendship of nations" and "fraternity of peoples" which had been meant to construct a multiethnic society in the USSR was shattered.

In 1989, approximately 25.3 million Russians were residing beyond the borders of the RSFSR, which corresponded to $18.5 \%$ of all Russians living in the USSR (Zaionchkovskaya, 1999: 11). The late 1980s marked the period during which Gorbachev's liberal policies and reforms had corollaries such as the rise of national self-consciousness, the declaration of Central Asian republics of their respective titular language as the official language, and the replacement of Russian party cadres by representatives of the titular nations. The latest waves of the Jewish emigration became concatenated with the permanent move of the Russian speaking population toward the RSFSR or the regions where Russian was still an official language, such as Kazakhstan. Towards the last years of perestroika and the beginning of independence, emigration of ethnic Russians to Russia increased rapidly. According to some sources, the number Russians living in Kazakhstan decreased from 6 million to 4.5 between 1989 and 1990. For the same period, the Kyrgyzstan lost around $34 \%$ of its ethnic Russian population. In Turkmenistan, where the percentage of Russians had reached 9.4 of the entire population in 1989, there are currently two percent of Russians residing (Peyrouse, 2007: 246-247). Additional incentives for Russian outmigration were the economic crisis in the USSR that resulted in wage differences between Russia and Central Asia as well as ethnic clashes that broke out in the region, which in turn bore discriminatory attitudes towards Russians that had until then been treated with privilege.

Towards the last years of the perestroika period, the USSR's emigration procedures became less strict, its relations with the Western countries improved, and reunified Germany started welcoming ethnic Germans from the former Soviet Union. Ethnic Germans who had been resettled during the Stalinist period in the Central Asian region and had started emigrating in fairly small numbers already during the 1970s began leaving in masses in 1990. The remaining Jews emigrated as well, switching their destination from Israel to the USA, then in addition to Western Europe, making Germany their primary destination in the 1990 s.

\section{MIGRATION PATTERNS IN CENTRAL ASIA AND RUSSIA IN THE 1990'S: THE FALL OF THE SOVIET UNION AND FURTHER INCREASE OF EMIGRATION AND MOBILITY RATE}

Between 1990 and 1999, Germany received 1.63 million ethnic Germans from the former Soviet Union in the framework of the German repatriation program (Spätaussiedler). Approximately 120,000 Jews emigrated from the ex-Soviet countries to Germany as well (Dietz, 2000: 1). The majority of these emigrants belonged to families who had been resettled forcefully during the Stalinist period to the Central Asian region, mainly to Kazakhstan. According to the data provided by the Statistical Committee of the 
Commonwealth of Independent States, 49,505 ethnic Germans left Kazakhstan in 1997 (IOM 1999: 76). From Kyrgyzstan, 2,183 ethnic Germans emigrated to their historical homeland within the same year (IOM, 1999: 91). The statistical information indicates that the number of ethnic Germans tended to be much smaller for other Central Asian countries for 1997. Uzbekistan, for instance, recorded the emigration of 917 ethnic Germans, Turkmenistan recorded 345, and Tajikistan, only 247. The reason for this stark difference is not only the large proportion of forced settlement of ethnic Germans primarily in Kazakhstan, but also the fact that many ethnic Germans emigrated already in the earliest years of the independence of their countries of residence and at a time when Germany did not yet require language proficiency for entry into Germany, i.e. prior to 1996. This is particularly true for Tajikistan where the outbreak of ethnic clashes and the Civil War in 1992 resulted in massive emigration and a sharp decline in the number of ethnic Germans. Whilst in 1989 33,000 ethnic Germans were registered as residing in Tajikistan (IOM, 1999: 139), the number of ethnic Germans and Jews that left Tajikistan between 1990 and 1992 amounted to 230,000, taken together (Bushkov, 2000: 155).

The emigration of ethnic Germans was not the only migratory consequence of the Civil War in Tajikistan. The violent clashes of 1992-1997 led other ethnic minorities as well thousands of Tajikistanis to leave the country. During this period 697,653 Tajikistanis were registered as internally displaced, however the majority returned to their place of origin in 1997. Thousands fled to Afghanistan, Uzbekistan, Kazakhstan, Turkmenistan, and Russia. The Russian Federal Migration Service reported in 1998 that 50,192 refugees and 126,625 forced migrants were residing in the Russian Federation. The majority of those who had fled to countries other than Russia had repatriated to Tajikistan when the conflicting parties signed a peace treaty in 1997. Those Tajiks who had been granted refugee status in Russia stayed permanently and have meanwhile obtained Russian citizenship. In 1997-1998, together with half of the 60,000 Tajiks who had fled to Afghanistan from the Civil War, Tajikistan received approximately 2,500 Afghans who had fled from the armed conflicts in Afghanistan. These people have meanwhile obtained refugee status in Tajikistan (IOM, 1999: 139-140).

The Russian-speaking population continued emigrating from all the Central Asian republics. Kazakhstan, while experiencing a major outflow of population, allowed all persons with Kazakh ancestry residing outside the borders of the republic to return to their historic homeland. By the mid-1990s, notwithstanding the repatriation of approximately 160,000 ethnic Kazakhs from the neighboring countries and due to large-scale emigration of ethnic minorities, the population of this country dropped from 17 million to 15 million. In 1998, the Government of Kazakhstan implemented a state-sponsored repatriation program in order to alleviate the demographic crisis. The program was conceptualized to facilitate the settlement of repatriates (oralman) by offering assistance to employment, access to a number of social benefits, and support of repatriates through integration programs (Darieva, 2005).

Similar to Kazakhstan, albeit on a much smaller scale, Kyrgyzstan and Turkmenistan also allowed ethnic Kyrgyz and Turkmen migrants to return to their respective historic homelands from neighboring countries, although the governments have not yet opted to provide the returnees with financial means. The International Organization 
for Migration is currently working together with NGOs and the Kyrgyz government to promote the development of a legal framework for a return project of ethnic Kyrgyz called kairylman (returnee).

Poor ecological conditions around the evaporating Aral Sea (Karakalpak Autonomous Province and Xorazm Region in Uzbekistan) forced thousands move to different areas. By 1997, the number of ecological migrants was reported to have reached 16,000 . Besides the economic crisis affecting all the republics of the former Soviet Union with the transition to the market economy, the governments of the Central Asian republics were confronted with challenges regarding domestic and foreign policies. Managing the migration of the population was hence not at the top of their agenda. Although the newly independent countries adopted their own citizenship policies and introduced citizenship passports that enabled their residents to travel rather freely, challenges such as irregular migration, illegal border-crossing, and trafficking in human beings did not gain much attention. Only towards the end of the 1990s and the beginning of the $21^{\text {st }}$ century did the governments start making efforts to solve these problems. ${ }^{20}$ Apart from Kazakhstan and Turkmenistan, three countries of the region, viz. Kyrgyzstan, Tajikistan, and Uzbekistan, have witnessed a large outflow of irregular labor migrants to Russia since the late 1990s and early 2000. According to official sources, there are approximately 5-7 million labor migrants in the Russian Federation and half of them are estimated to be from Central Asian countries (IOM, 2008).

\section{CONCLUSION}

We have seen in this article that labor migration from Central Asia to Russia as it exists today has been structured by a complex array of political, economic and social factors. Through the historical trajectory of migrations from the earliest days of the Soviet Union until its demise in 1991, it has been illustrated that the population of the Soviet Union not only had strict constraints to movement but also was subject to forced relocations between different regions. Nonetheless, Soviet citizens increasingly engaged themselves in rural-to-urban migrations which expanded the urban population to a considerable extent. As far as Central Asia is concerned, it has been shown that the region continuously experienced as much in-migration as out-migration of people.

It has been illustrated in this article that labor migrants from Central Asia to Russia started to arrive already during the Soviet period. The current flow of labor force is therefore not an entirely new phenomenon. The party-state managed labor migration of Central Asia's workable population to Russia in the late 1970s and early 1980s was to enhance production through the cultivation of virgin lands. Together with Central Asian recruitees in the Soviet Army in Russia and Central Asian students at Russian higher education institutions, this generation of pioneer labor migrants may have played a significant role in the formation of migrant networks.

20 See IOM reports between 1999 and 2002.

REMI 2010 (26) 3 pp. 9-30 
In studying the current patterns of migration and, in particular, increased labor migration, we should bear in mind the ethnic heterogeneity of the population in this region. The three countries of origin (Kyrgyzstan, Tajikistan, and Uzbekistan) share a common Soviet past: it started with the annexation of their historical territories to the Russian Empire, the process of administrative territorial border demarcation in the 1920s and 1930s and the creation of nationalities by the Soviet state, and it continued as the states underwent the Sovietization processes, including the ideological project of 'friendship and brotherhood of nations' that gradually molded the society in the region.

\section{References}

ABAZOV Rafiz (2000) Migration of Population, the Labor Market and Economic Changes in Kirghizstan, in Hisao Komatsu, Chika Obiya and John S. Schoeberlein Eds., Migration in Central Asia: Its History and Current Problems, JCAS Symposium Series 9, Osaka, Japan Center for Area Studies, National Museum of Ethnology, pp. 209-235.

BERDINSKIKH Viktor (2005) Spetsposelentsy. Politicheskaia ssylka narodov sovetskoi Rossii [Special settlers. Political Exile of the Peoples of the Soviet Russia], Moscou, Novoe Literaturnoe Obozrenie, $527 \mathrm{p}$.

BERTHOMIĖRE William (2003) Immigration from the Former Soviet Union. Measure of the Impacts on Jerusalem and on the Settlements of the West Bank and Gaza, The Arab World Geographer, 6 (2), pp. 249-264.

BUCKLEY Cynthia (1995) The Myth of Managed Migration. Migration Control and Market in the Soviet Period, Slavic Review, 54 (4), pp. 896-916.

BUCKLEY Cynthia, RUBLE Blair A. and HOFMANN Erin T. (Eds.) (2008), Migration, Homeland and Belonging in Eurasia, Baltimore, Johns Hopkins University Press, 362 p.

BUGAI N.-F. and KOTSONIS A.-N. (1999) “Obiazat' NKVD SSSR ...vyselit' grekov”, "Assign the NKVD of the USSR to relocate the Greeks", Moscou, Insan, 159 p.

BUSHKOV Valentin I. (2000) Population Migration in Tajikistan: Past and Present, in Hisao Komatsu et al. Eds., Migration in Central Asia: Its History and Current Problems, JCAS Symposium Series 9, Osaka, Japan Center for Area Studies, National Museum of Ethnology.

BUWALDA Petrus (1997) They Did not Dwell Alone. Jewish Emigration from the Soviet Union 1967-1990. Washington DC, The Woodrow Wilson Center Press, Baltimore and London, The Johns Hopkins University Press, 297 p.

COLLINS Kathleen (2006) Clan Politics and Regime Change in Central Asia, Cambridge, New York, Cambridge University Press.

DARIEVA Tsypylma (2005) Recruiting for the Nation: Post-Soviet Transnational Migrants in Germany and Kazakhstan, Siberian Studies, http://www.siberianstudies.org/publications/PDF/ ridarieva.pdf.

DIETZ Barbara (2000), German and Jewish migration from the former Soviet Union to Germany: background, trends and implications, Journal of Ethnic and Migration Studies, 26 (4), pp. 635-652.

EDGAR Adrienne L. (2004) Tribal Nation: The Making of Soviet Turkmenistan, Princeton, Princeton University Press, $296 \mathrm{p}$.

GARCELON Marc (2001) Colonizing the Subject: The Genealogy and Legacy of the Soviet Internal Passport, in Jane Caplan and John Torpey Eds., Documenting Individual Identity. The Development of State Practices in the Modern World, Princeton and Oxford, Princeton University Press, pp. 83-100. 
GIBSON James R. (1991) Interregional Migration in the USSR, 1981-1985 and 1971-1975, The Canadian Geographer/Le Géographe canadien, 35 (2), pp. 142-156.

HIRSCH Francine (2005) Empire of the Nations. Ethnographic Knowledge and the Making of the Soviet Union, Ithaca and London, Cornell University Press, 367 p.

IOM INTERNATIONAL ORGANIZATION FOR MIGRATION (1999) Migration in the CIS 19971998, IOM Publications, $215 \mathrm{p}$.

IOM INTERNATIONAL ORGANIZATION FOR MIGRATION (2008) Migration in the Russian Federation. A Country Profile 2008, IOM Publications, 104 p.

ISLAMOV Bakhtior (2000) Migration of Population in Independent States of Central Asia, in Hisao Komatsu, Chika Obiya and John S. Schoeberlein Eds., Migration in Central Asia: Its History and Current Problems, JCAS Symposium Series 9, Osaka, Japan Center for Area Studies, National Museum of Ethnology, pp. 179-197.

KOCAOĞLU Timur (2000) Turkistan Abroad: The Political Migration - From the Soviet and Chinese Central Asia (1918-1997), in Hisao Komatsu, Chika Obiya and John S. Schoeberlein Eds., Migration in Central Asia: Its History and Current Problems, JCAS Symposium Series 9, Osaka, Japan Center for Area Studies, National Museum of Ethnology, pp. 113-126.

KOROBKOV Andrei V. (2008) Post-Soviet Migration: New Trends at the Beginning of the TwenyFirst Century, in Cynthia J. Buckley, Blair A. Ruble and Erin T. Hofmann Eds., Migration, Homeland and Belonging in Eurasia, Baltimore, Johns Hopkins University Press, pp. 69-98.

KOMATSU Hisao, Chika OBIYA and John S. SCHOEBERLEIN (Eds.) (2000) Migration in Central Asia: Its History and Current Problems. JCAS Symposium Series 9, Osaka, Japan Center for Area Studies, National Museum of Ethnology, $245 \mathrm{p}$.

LEWIS Robert A. and Richard ROWLAND (1979) Population redistribution in the USSR: its impact on society, 1897-1977, New York, Praeger, 485 p.

LUBIN Nancy (1984) Labor and Nationality in Soviet Central Asia. An Uneasy Compromise, Hong Kong, MacMillan Press, 305 p.

MATTHEWS Mervyn (1993) The Passport Society. Controlling Movement in Russia and the USSR, Boulder, San Francisco, Oxford, Westview Press, 118 p.

MEGORAN Nick (2002) The borders of eternal friendship? The politics and pain of nationalism and identity along the Uzbekistan-Kyrgyzstan Ferghana Valley boundary, 1999-2000, PhD Dissertation defended at Sydney Sussex College, Cambridge, UK, http://www.staff.ncl.ac.uk/ nick.megoran/pdf/nick_megoran_phd.pdf.

PEYROUSE Sébastien (2007) Rückkehr und Aufbruch. Zentralasiatische Migrationsströme, in Machtmosaik Zentralasien. Traditionen, Restriktionen, Aspirationen, Osteuropa, 57 Jahrgang, 8, Stuttgart, Deutsche Verlags-Anstalt, pp. 245-255.

POLYAN Pavel (2001) Ne po svoei vole. Istoriia i geografiia prinuditel'nykh migraciy v SSSR [Not by their own will. History and geography of forced migrations in the USSR]: Publication of the Human Rights Organization Memorial.

ROMAN Meredith (2002) Making Caucasians Black: Moscow Since the Fall of Communism and the Racialization of Non-Russians. Journal of Communism Studies and Transition Politics, 18 (2), pp. 1-17.

ROY Olivier (2000) The New Central Asia: Geopolitics and the Birth of Nations, New York, I.B. Tauris, $240 \mathrm{p}$.

RUBIN Barnett R. and Nancy LUBIN (Eds.) (1999) Calming the Ferghana Valley. Development and Dialogue in the Heart of Central Asia, Report of the Ferghana Valley Working Group of the Center for Preventive Action, New York, The Century Foundation Press, 196 p.

RYVKINA Rozalina V. (1996) Yevrei v postsovetskoi Rossii - Kto oni? Sotsiologicheskii analiz problem rossiiskogo evereistva [Jews in Post-Soviet Russia - Who are They? Sociological Analysis of Problems Related to Russian Jewishness] (In Russian.) Moskva, URSS.

SAHADEO Jeff (2007) 'Druzhba Narodov' or second class citizenship? Soviet Asian migrants in a post-colonial world, Central Asian Survey, 26 (4), pp. 559-579. 
SHIGABDINOV Rinat and NIKITENKO Georgii (2000) Migration Processes in the West of Central Asia in the Late Nineteenth and the Twentieth Centuries, in Hisao Komatsu, Chika Obiya and John S. Schoeberlein Eds., Migration in Central Asia: Its History and Current Problems, JCAS Symposium Series 9, Osaka, Japan Center for Area Studies, National Museum of Ethnology, pp. 87-111.

SMITH Graham (1996) The Nationalities Question in the Post-Soviet States, $2^{\text {nd }}$ Edition. London and New York, Longman, 389 p.

WIMBUSH S. Enders and PONOMAREFF Dmitry (1979) Alternatives for Mobilizing Soviet Central Asian Labor: Outmigration and Regional Development, A Project AIR FORCE report prepared for the United States Air Force, Santa Monica, CA, Rand Corporation, 38 p.

ZASLAVSKY Viktor and BRYM Robert J. (1983) Soviet-Jewish Emigration and Soviet Nationality Policy, Hong Kong, The Macmillan Press, 185 p.

ZAIONCHKOVSKAYA Zhanna A. (1999) Vnutrenniaia migraciia $v$ Rossii $i v$ SSSR $v$ XX veke kak otrajenie social'noi modernizacii [Internal Migration in Russia and the USSR in the $20^{\text {th }}$ century as the Reflection of Social Modernization], in Mir Rossii, 4, pp. 22-34, http://www.ecsocman. edu.ru/data/546/989/1219/1999_n4_p22-34.pdf (05/12/2010). 


\title{
Migrations during the Soviet Period and in the Early Years of USSR's Dissolution: A Focus on Central Asia
}

\author{
Delia RAHMONOVA-SCHWARZ
}

\begin{abstract}
Contemporary mass flow of labor migrants from particularly Kyrgyzstan, Tajikistan and Uzbekistan to Russia is a topic which has been increasingly attracting the attention researchers on Central Asia. Yet how new is this phenomenon really? This article illustrates migrations between Central Asia and Russia from the early years of the Soviet period until the beginning of a new era marked by the fall of the USSR. It explains the opportunities for and constraints on population mobility during the Soviet period. Strict control of population movements and forced resettlement programs which took place especially during the Stalinist period influenced the ethnic composition in the region. This article also elaborates on the party-state's management of labor force in the late 1970s and early 1980s especially state-supported migration to Russia to enhance production through the cultivation of virgin lands.
\end{abstract}

\section{Migrations pendant la période soviétique et après la fin de l'URSS : regard sur l'Asie centrale}

\author{
Delia RAHMONOVA-SCHWARZ
}

Les flux contemporains de travailleurs migrants originaires du Kirghizstan, du Tadjikistan ou bien encore d'Ouzbékistan vers la Russie sont devenus un objet de recherche parmi les spécialistes de l'Asie centrale. Cet article vise à dresser un panorama de ces migrations du début de la période soviétique jusqu'aux premières années de la période post-soviétique. L'auteure décrit les dynamiques migratoires et la diversité des facteurs qui ont pu conduire à un accroissement ou à une restriction des flux. Elle analyse les conséquences du contrôle strict opéré sur les mouvements de populations et les déplacements forcés pendant le stalinisme et sur la composition ethnique de l'espace centre asiatique. Enfin l'auteure explore les politiques migratoires de l'Union soviétique liées à la gestion de la main-d'œuvre et au développement économique des terres vierges de Russie.

\section{Migraciones durante el período soviético y los primeros años después de la caída de la URSS: acento en Asia central}

\author{
Delia RAHMONOVA-SCHWARZ
}

El flujo contemporáneo de los trabajadores migrantes procedentes de Kirguistán, Tayikistán y Uzbekistán hacia Rusia es un tema que atrae cada vez más la atención de los investigadores sobre Asia central. Sin embargo podemos preguntarnos si se trata realmente de un fenómeno nuevo. Este artículo ilustra las migraciones entre Asia central y Rusia desde el principio del período soviético hasta los primeros años después de la descomposición de la Unión soviética. Explica las oportunidades y restricciones de la movilidad durante el período soviético. El estricto control de los movimientos de población y los programas de desplazamiento forzados durante el estalinismo han influenciado la composición étnica de la región de Asia central. Este artículo evoca también la gestión de la mano de obra por el partido-Estado a finales de los años 70 y principios de los años 80 , y en particular la migración hacia Rusia apoyada por el estado con el fin de favorecer la producción mediante la explotación agrícola de terrenos rusos vírgenes. 